\title{
COMPLETE UTERINE RUPTURE: A CASE REPORT
}

\author{
Kemine Uzel
}

Derince Training and Research Hospital, University of Health Sciences, Kocaeli, Turkey

\section{POTPUNA RUPTURA MATERICE: PRIKAZ SLUČAJA \\ Kemine Uzel \\ Bolnica za obuku i istraživanje Derince, Univerzitet medicinskih nauka, Kocaeli, Turska}

\begin{abstract}
Background: Uterine rupture during pregnancy is a considerable obstetric complication. The presence of a previous uterine scar is the most significant risk factor. Early clinical diagnosis is paramount to maternal and fetal survival. Case Report: A 36year-old woman, gravida 2 para 2 , presented with sudden acute abdominal pain at 38 weeks of gestation. The patient had a history of cesarean delivery one year ago. Ultrasound scans showed an empty endometrial cavity and fetus outside the uterus. Emergency laparotomy was performed, a live baby boy weighing $3.420 \mathrm{~kg}$ was delivered, and the uterine disruption was repaired. Conclusion: Increasing trends in the cesarean section may lead to a higher number of uterine ruptures. The survival of patients after uterine rupture depends on the time interval between rupture and intervention, and the availability of appropriate medical team and equipment. Health professionals caring for pregnant women should be alert for the symptoms and risk factors of uterine rupture.
\end{abstract}

Keywords: Hemoperitoneum, Pregnancy, Uterine Rupture,

\section{SAŽETAK}

Sažetak: Ruptura materice tokom trudnoće je značajna akušerska komplikacija. Prisustvo prethodnog ožiljka materice je najznačajniji faktor rizika. Rana klinička dijagnoza je ključna za preživljavanje majke i fetusa. Žena stara 36 godina, imala je iznenadni akutni bol u stomaku u 38. nedelji gestacije. Pacijentkinja je imala istoriju porođaja carskim rezom pre godinu dana. Ultrazvučni pregledi su pokazali praznu endometrijalnu šupljinu i fetus izvan materice. Urađena je hitna laparotomija, rođena živa beba, težine $3,420 \mathrm{~kg}$, $i$ saniran poremećaj materice. Zaključak: Sve veći trend carskog reza može dovesti do većeg broja ruptura materice. Opstanak pacijenata nakon rupture materice zavisi od vremenskog intervala između rupture i intervencije i dostupnosti odgovarajućeg medicinskog tima i opreme. Zdravstveni radnici koji se brinu o trudnicama treba da budu upozoreni na simptome i faktore rizika od rupture materice.

Ključne reči: hemoperitoneum, trudnoća, ruptura materice 


\section{INTRODUCTION}

Rupture of the pregnant uterus is an unusual but lifethreatening obstetrical situation, which is associated with high perinatal and maternal morbidity and mortality $[1,2]$. This unusual complicationis a nonsurgical disruption of some or all layers of the uterus. The prevalence of uterine rupture was reported as 5.3 per 10,000 deliveries [1].Uterine rupture generally occurs during the third trimester of pregnancy or during delivery, and the most significant risk factor is the presence of a uterine scar resulting from a prior cesarean delivery or myomectomy [3]. However, also spontaneous rupture of an un-scarred uterus during pregnancy is possible [4].

The clinical presentation of a gravid uterine rupture can include acute abdominal pain, vaginal bleeding, uterine overtone, altered fetal heart rate or fetal bradycardia and, more rarely, hypotension and hypovolemic shock [5]. The rate of cesarean deliveries has increased recently in most countries, varying from $15 \%$ to $40 \%$ of deliveries [6]. The alarming rates of cesarean deliveriesin Turkey warrants caution for primary care physicians and obstetricians in detecting this potentially serious condition [7] and bring a challenge to the managing surgical team. We report a case uterinerupture, which could be managed conservatively.

\section{CASE REPORT}

A 36-year-old woman G2P2 presented with a history of previous cesarean section 1 year ago. Thepatient's first birth occurred in May 2017 with cesarean delivery at 39 weeks gestation due to thedevelopment of fetal distress and chorioamnionitis. Because of an intraabdominal abscess, she received surgical drainage of the abscess and an antibiotic regimen for 28 days.

The patient was seen at a routine visit at 38-weeks-gestation on the $22^{\text {nd }}$ of November 2018 at noontime without any remarkable findings, including a normal non-stress test (Figure 1). There was no pain or distress during the examination. She had no known medical problems and was not on anymedications. Besides, she was a nonsmoker and a teetotaler. Her body mass index was calculated as $27.3 \mathrm{~kg} / \mathrm{m}^{2}$. A follow-up visit was scheduled for three days later. However, in the evening of the sameday at 22:05h, the patient was admitted to the emergency unit with abdominal pain starting at around $20: 20 \mathrm{~h}$.

The patient had profuse vaginal bleeding with severe hypotension, tachycardia, and intense abdominal pain. Her blood pressure was $70 / 40 \mathrm{mmHg}$, and her pulse was 110 beats per minute. Theabdomen was distended and tender on palpation. Fetal bradycardia was observed in the ultrasound examination. The ultrasound scan showed an empty endometrial cavity and the fetus outside the uterus. Suspecting uterine rupture and abruptio of placenta the patient underwent emergency laparotomy for surgical exploration under general anesthesia at 22:10h. Noimages were recorded due to emergency conditions and endangered maternal and fetal life.

Three 18-gauge intravenous cannulas were secured, and one liter Ringer's lactate was infused rapidlybefore the induction of anesthesia. Induction was done with $100 \mathrm{mg}$ ketamine and $100 \mathrm{mg}$ celocurine intravenously, and rapid sequence tracheal intubation was done employing the Sellick's maneuver.

Anesthesia was maintained with oxygen, air and $2 \%$ sevoflurane. The abdomen was opened by a Pfannenstiel incision. Exploration demonstrated that the previous cesarean section scar was completely ruptured. A baby boy weighing $3.420 \mathrm{~kg}$ was delivered. The newborn had an Apgar scoreof $4 / 7$ at $1 / 5$ minutes. The rupture was closed in layers followed by peritoneal cleaning. A hysterectomy was not considered. The blood loss was estimated at $1500 \mathrm{ml}$. The patient received two units of packed red blood cells, two units of fresh frozen plasma, $1500 \mathrm{ml}$ of lactated Ringer's solution, and $2000 \mathrm{ml}$ of $0.9 \%$ saline. Her hemoglobin level the day after surgery was $8 \mathrm{~g} / \mathrm{dL}$. The platelet counts and fibrinogen levels, prothrombin time, partial thromboplastin time, lactate levels, as well as arterial blood gas and $\mathrm{pH}$ analyses, were within the normal range during and after the intervention.

After four days of hospitalization, the patient was discharged with a hemoglobin level of $8.9 \mathrm{~g} / \mathrm{dL}$.

\section{DISCUSSION}

The risk factors for uterine rupture during pregnancy are described as grand multiparity, short lengthof time since cesarean delivery or myomectomy, high number of cesarean deliveries, use of uterotonic drugs (oxytocin and prostaglandins) during the induction of labor, dystocia, macrosomia, multiple gestation, maternal age $>35$ years, abnormal placentation, and the presence of uterine anomalies [8,9]. Besides, less than 6 months interval between two successive pregnancies, body mass index (BMI) higher than $50 \mathrm{~kg} / \mathrm{m}^{2}$, tobacco use, birth weight more than 4000 grams, postmaturity past 42 weeks gestation, instrumental vaginal delivery, and low socio-economic status were also accused as risk factors [10]. However, previous cesarean scar accounts for the most common risk factor. Vilchez et al. [11] reviewed deliveries in the USA and reported 1925 uterine ruptures out of around 8 million births $(2.4 / 10,000)$ of which $969,957(19.8 / 10,000)$ were women with prior cesarean deliveries. On the other hand, grand multiparity ( $\geq 7$ deliveries) accounted for $12.4 \%$ of all uterine ruptures while short inter-pregnancy period has been observed in $12.0 \%$ of all uterine ruptures [12]. The presented case carries some of the risk factors including a recent cesareandelivery and age above 35 years.

There is no strict agreement in the management of pregnant women with previous cesarean sections. Since patients with a classical hysterotomy are more prone to rupture during pregnancy, they were suggested to deliver by $36-37$ weeks 
gestation [12]. However, a planned cesarean deliveryat 38 weeks gestation was also proposed [13]. Additionally, a single-layer closure of the previous lower segment incision is associated with a fourfold increase in the risk of uterine rupture compared with a double-layer closure [14]. Uterine rupture with hemorrhagic shock is a surgical challenge; the unstable hemodynamics requires judicious care and experience. Urgent surgical exploration to achieve hemostasis is a necessity. The aim of management should be to stop the hemorrhage, repair the anatomic damage, and decrease morbidity with surgical repair or a hysterectomy, depending on several factors such as the size of the uterine defects, patient age, and comorbidity factors. A conservative approach avoided hysterectomyin this case. However, the rate of cesarean deliveries in Turkey shows a never-ending increasing trend. According to the Turkey Demographic and Health Survey (DHS) 2003 report [15], $21 \%$ of babies were born with CS, which increased to $36.7 \%$ in 2008 [16], 48\% in 2013 [17], and $53.1 \%$ in 2016 [18]. Thus, an increased number of uterine ruptures should be expected in the future, if no immediate precautions are taken to reverse the high cesarean section rates.

\section{CONCLUSION}

Rupture of the pregnant uterus is an unusual but severe obstetric situation, which is associated with high perinatal and maternal morbidity and mortality. It often presents atypically, which makes it hardto detect based on clinical and physical examination only. The major risk factor of this surgical disorder is a "scarred uterus" due to previous cesarean section, but a rupture of the pregnant uterus should always be considered in a pregnant woman presenting with abdominal pain. Early diagnosis and prompt treatment of uterine rupture may mainly improve prognosis. The survival of patients after uterine rupture depends on the time interval between rupture and intervention, and the availability of blood products for transfusion. Given the increasing trend of cesarean section deliveries, higher number of similar complications may be expected in the future.

Figure 1. The non-stress test obtained earlier in the day of the uterine rupture while the patient was asymptomatic.

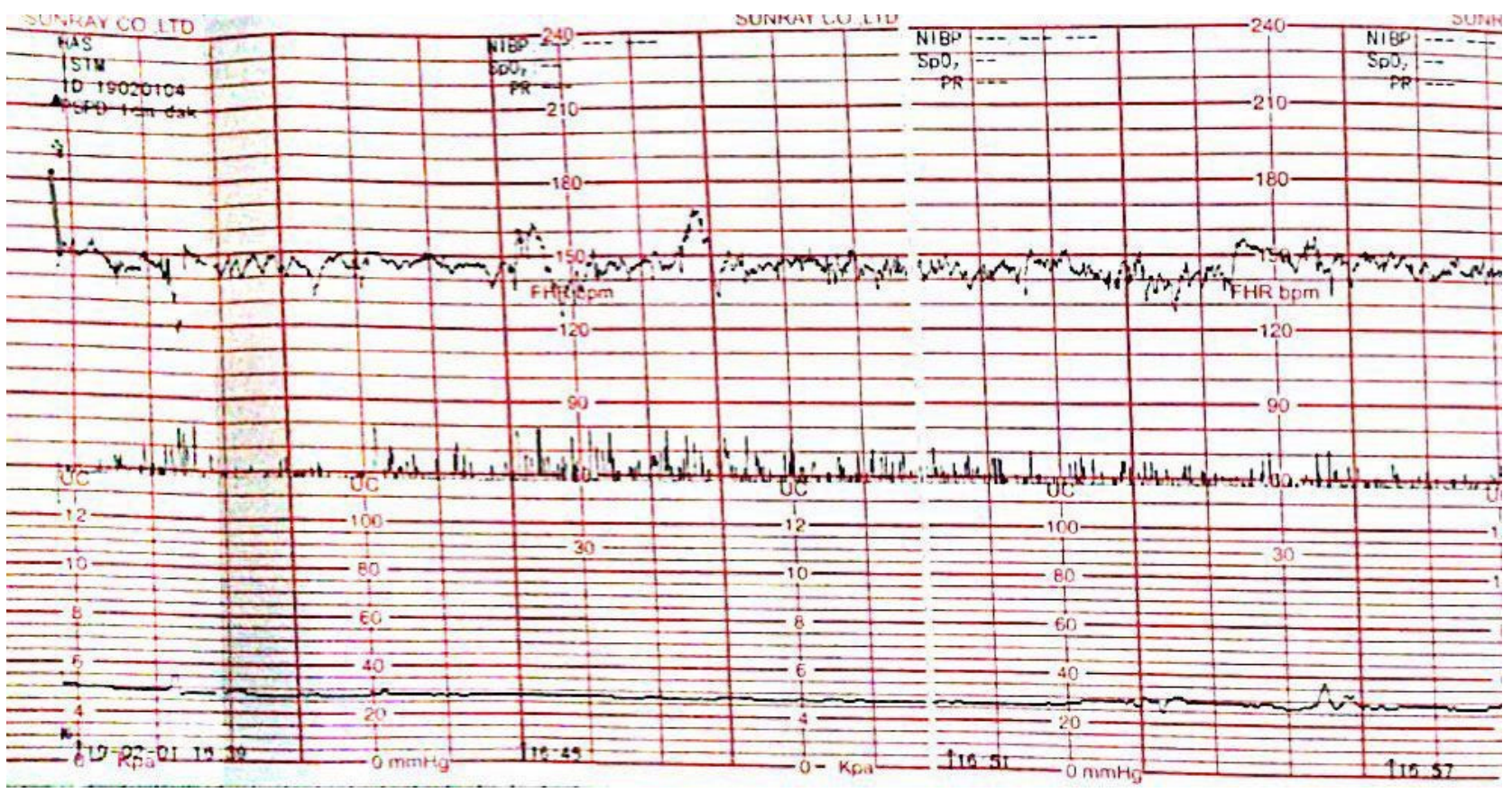

\section{ACKNOWLEDGMENTS}

I would like to thank Dr. U. Aytekin for his support.

\section{COMPETING INTERESTS}

The author has no competing interests for this paper.

\section{FUNDING}

This study has received no financial support.

\section{AVAILABILITY OF DATA AND MATERIALS}

The datasets used during the current study are available from the corresponding author on reasonable request 


\section{CONFLICT OF INTEREST}

The author declares that there is no conflict of interest regarding the publication of this paper.

\section{CONSENT FOR PUBLICATION}

The patient gave written consent for the publication of this manuscript.

\section{ETHICS APPROVAL AND CONSENT TO PARTICIPATE}

The study protocol for the reported case was approved by the Derince Training and Research Hospital, Kocaeli, Turkey. The patient gave her written consent to publish the results. Caution was given not to violate any human rights in this article.

\section{LITERATURE}

1. Justus Hofmeyr G, Say L, Metin Gülmezoglu A. Systematic review: WHO systematic review of maternal mortality and morbidity: the prevalence of uterine rupture. BJOG An Int J Obstet Gynaecol 2005;112:1221-8.

2. Sağlamtas M, Vicdan K, Yalcin H, Yilmaz Z, Yeşilyurt $\mathrm{H}$, Gökmen O. Rupture of the uterus. Int J Gynecol Obstet 1995;49:9-15.

3. Endres LK, Barnhart K. Spontaneous second trimester uterine rupture after classical cesarean. Obstet Gynecol 2000;96:806-8.

4. Pontis A, Prasciolu C, Litta P, Angioni S. Uterine rupture in pregnancy: two case reports and review of literature. Clin Exp Obstet Gynecol 2016;43:304-9.

5. Walsh CA, Baxi L V. Rupture of the primigravid uterus: a review of the literature. Obstet Gynecol Surv 2007;62:327-34.

6. Deneux-Tharaux C. [Women with previous caesarean or other uterine scar: epidemiological features]. J Gynecol Obstet Biol Reprod (Paris) 2012;41:697-707. doi:10.1016/j.jgyn.2012.09.022.

7. Kucuk M. Obstetrician perceptions of the causes of high cesarean delivery rates in Turkey. Int J Gynaecol Obstet 2017;138:100-6. doi:10.1002/ijgo.12172.
8. Abdalla N, Reinholz-Jaskolska M, Bachanek M, Cendrowski K, Stanczak R, Sawicki W. Hemoperitoneum in a patient with spontaneous rupture of the posterior wall of an unscarred uterus in the second trimester of pregnancy. BMC Res Notes 2015;8:603.

9. Zwart JJ, Richters JM, Öry F, De Vries JIP, Bloemenkamp KWM, Van Roosmalen J. Uterine rupture in the Netherlands: a nationwide population-based cohort study. BJOG An Int J Obstet Gynaecol 2009;116:106980.

10. Colmorn LB, Petersen KB, Jakobsson M, et al. The Nordic Obstetric Surveillance Study: a study of complete uterine rupture, abnormally invasive placenta, peripartum hysterectomy, and severe blood loss at delivery. Acta Obstet Gynecol Scand 2015;94:734-44. doi:10.1111/aogs.12639.

11. Vilchez G, Nazeer S, Kumar K, Warren M, Dai J, Sokol RJ. Contemporary epidemiology and novel predictors of uterine rupture: a nationwide population-based study. Arch Gynecol Obstet 2017;296:869-75. doi:10.1007/s00404-017-4508-4.

12. Teguete I, Traore Y, Sissoko A, et al. Determining factors of cesarean delivery trends in developing countries: lessons from point G National Hospital (Bamako-Mali). Cesarean Deliv., InTech; 2012.

13. Landon MB, Lynch CD. Optimal timing and mode of delivery after cesarean with previous classical incision or myomectomy: a review of the data. Semin. Perinatol., vol. 35, Elsevier; 2011, p. 257-61.

14. Bujold E, Bujold C, Hamilton EF, Harel F, Gauthier RJ. The impact of a single-layer or double- layer closure on uterine rupture. Am J Obstet Gynecol 2002;186:132630 .

15. Turkey Demographic and Health Survey 2003. Ankara: 2003.

16. Turkey Demographic and Health Survey 2008. Ankara: 2008.

17. Turkey Demographic and Health Survey 2013. Ankara: 2013.

18. Köse MR, Bora Başara B, Soytutan Çağlar I, et al. Republic of Turkey Ministry of Health. Health Statistics Yearbook 2016. Ankara: 2017. 